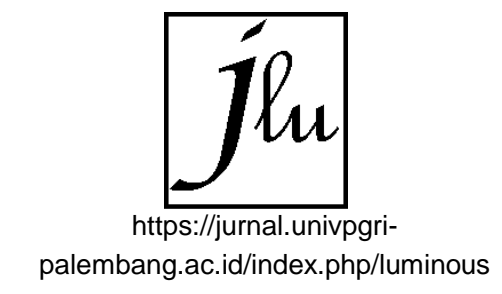

Jurnal Luminous:

\title{
PENGARUH PENERAPAN MODEL PEMBELAJARAN INTERACTIVE LECTURE EXPERIMENT (ILE) BERBANTUAN MEDIA SIMULASI VIRTUAL TERHADAP PENURUNAN KUANTITAS SISWA YANG MISKONSEPSI PADA MATERI LISTRIK DINAMIS
}

\author{
Minarni ${ }^{1}$, Yudi Kurniawan ${ }^{2}$, Riski Muliyani ${ }^{3}$ \\ 1,2,3Prodi Pendidikan Fisika STKIP Singkawang \\ 1'minarni0123@gmail.com, ${ }^{2} y u d i k u r n i a w a n 1012 @ g m a i l . c o m, ~{ }^{3}$ kikiriski1012@gmail.com
}

\begin{abstract}
Abstrak
Penelitian ini bertujuan untuk mengetahui pengaruh penerapan model pembelajaran Interactive Lecture Experiment (ILE) berbantuan media simulasi virtual terhadap penurunan kuantitas siswa yang miskonsepsi pada materi Listrik Dinamis. Dalam penelitian ini terdapat tujuh miskonsepsi pada sub materi Listrik Dinamis. Penelitian ini merupakan penelitian kuantitatif dengan menggunakan one group pretest-posttest design. Sampel dalam penelitian ini adalah satu kelas dari keseluruhan siswa kelas $X$ yang terdapat di SMA Negeri Kota Singkawang yaitu sebanyak 30 orang, dengan tes diagnostik berbentuk pilihan ganda menggunakan format three tier-test (TTT). Hasil uji statistik yaitu dengan menggunakan rumus Descreasing Quantity Students Misconception (DQM) yang menunjukan konsep listrik dinamis yang mengalami penurunan kuantitas siswa yang miskonsepsi dengan persentase terbesar (76\%) yaitu "arus listrik adalah muatan positif yang mengalir dalam konduktor dari kutub positif baterai menuju kutub negatif baterai", dan model pembelajaran ILE berbantuan media simulasi virtual ini dapat menurunkan kuantitas siswa yang miskonsepsi dengan rata-rata $46,3 \%$ berkategori sedang. Diharapkan untuk peneliti selanjutnya menggunakan model ILE dalam melaksanakan eksperimen menggunakan kelompok belajar kecil supaya dalam pembelajaran selanjutnya peneliti akan lebih mudah mengawasi siswa dalam bereksperimen dan akan lebih mudah dalam pengambilan data.
\end{abstract}

Kata kunci: Interactive Lecture Experiment, Media Simulasi Virtual, Miskonsepsi Siswa

(C) 2020 Pendidikan Fisika FKIP UPGRI Palembang

\section{PENDAHULUAN}

Sebelum memulai pembelajaran fisika terkadang di dalam pemikiran siswa sudah tertanam suatu konsep awal yang mereka peroleh dari pengalaman kehidupan sehari-hari. Pengalaman tersebut membentuk intuisi siswa mengenai konsep fisika yang belum tentu itu benar dengan konsep ilmiah menurut para ahli, ketidak sesuaian intuisi siswa terhadap konsep ilmiah berdasarkan para ahli tersebut disebut dengan miskonsepsi (Suparno, 2005).
Miskonsepsi adalah siswa yang beranggapan bahwa konsepsi yang dimilikinya benar dan mengabaikan konsep ilmiah, sehingga dalam pembelajaran pemikiran siswa akan bertolak belakang dengan para ilmuan (Kurniawan, Yudi dkk, 2016). Selain itu, miskonsepsi adalah suatu konsepsi yang melekat pada benak siswa yang sebenarnya menyimpang dari konsep yang dikemukakan oleh para ahli, dimana akan membuat siswa keliru dalam memahami fenomena alamiah (Muna, I. Auliyatul, 2015). 
Dalam penelitian ini, peneliti mencoba memecahkan masalah yang terkait miskonsepsi pada materi fisika. Satu di antara materi fisika yang cenderung banyak memiliki miskonsepsi adalah materi listrik dinamis. Beberapa siswa listrik adalah muatan positif yang mengalir dalam konduktor dari kutub positif baterai ke kutub negatif baterai dan kuat arus listrik yang mengalir melewati setiap titik dalam suatu rangkaian seri nilainya bergantung pada jarak titik tersebut terhadap kutub-kutub baterai (Suparno, 2005). Oleh karena itu, miskonsepsi yang dimiliki siswa harus diperbaiki sedini mungkin, jika tidak akan mengakibatkan miskonsepsi yang berlanjut (Pebriyanti, dkk, 2015).

Untuk mengatasi terjadinya miskonsepsi tersebut peneliti memberikan solusi alternatif yaitu memberikan pembelajaran konstruktivis yang menimbulkan konflik kognitif dengan menerapkkan model pembelajaran Interactive Lecture Experiment (ILE), adapun tahapantahapan yang terdapat di model pembelajaran ILE yaitu, 1) demonstrasi, 2) eksperimen, 3) analisis, 4) mempresentasikan, 5) pemecahan suatu masalah (Moll, Rachel dkk, 2009). Model pembelajaran ILE merupakan model yang dapat mengetahui terjadinya miskonsepsi pada siswa melalui eksperimen langsung terhadap fenomena-fenomena dalam konsep fisika (Milner-Bolotin, dkk, 2009).

Dengan adanya eksperimen maka diperlukan suatu laboratorium untuk siswa melakukan praktikum, karena adanya terdapat suatu materi yang bersifat abstrak yang sulit untuk diatasi dan dipahami contohnya mengamati aliran elektron di kutub negatif ke masih miskonsepsi terhadap rangkaian listrik dimana siswa berpendapat bahwa dalam rangkaian terbuka tidak ada beda tegangan, dan beberapa bentuk miskonsepsi lainnya yaitu arus positif maka akan menghambat pembelajaran fisika di laboratorium. Untuk mengatasi hal tersebut maka sebagai pelengkap dalam model pembelajaran ILE untuk mengeksperimenkan diperlukan media simulasi virtual.

Media simulasi virtual dapat digunakan sebagai sarana pembelajaran dimana dapat menggantikan peran alat-alat peraga yang mana tidak bisa dilihat secara langsung, keterbatasan alat dan meminimalisir resiko kecelakaan (Suniati, dkk, 2015). Dengan adanya media simulasi virtual yaitu sebagai sarana dalam mengkonstruksi konsep siswa, maka akan memicu terjadinya keadaan konflik kognitif dan dapat meningkatkan aktifitas belajar siswa sehingga dapat meningkatkan penguasaan konsep siswa dan meminimalkan miskonsepsi yang dimiliki siswa sebelumnya (Hikmat, dkk, 2014).

Berdasarkan uraian tersebut, maka peneliti ingin mengetahui pengaruh penerapan model pembelajaran ILE berbantuan media simulasi virtual terhadap penurunan kuantitas siswa yang miskonsepsi pada materi listrik dinamis di salah satu SMA Negeri di Kota Singkawang.

\section{METODE PENELITIAN}

Penelitian ini merupakan penelitian kuantitatif dengan menggunakan one group pretest-posttest design. Populasi dalam 
penelitian ini adalah seluruh siswa kelas $X$ yang termasuk salah satu dari SMA Negeri Kota Singkawang. Sampel dalam penelitian ini adalah satu kelas dari keseluruhan siswa kelas $X$ yang terdapat di SMA Negeri Kota Singkawang yaitu sebanyak 30 orang, dengan teknik pengambilan sampel yaitu purposive sampling, dengan pertimbangan siswa yang telah mempelajari konsep Listrik Dinamis.

Teknik pengumpulan data yang digunakan dalam penelitian ini yaitu tes dan non tes. Adapun non tes yang digunakan yaitu berupa lembar observasi keterlaksanaan model pembelajaran ILE berbantuan media simulasi virtual dan tes skala sikap yang diberikan kepada sampel berupa pernyataan-pernyataan dalam bentuk lembar skala sikap yang bertujuan untuk mengetahui respon siswa terhadap proses pembelajaran yang telah dialami siswa, sedangkan tes diagnostik yaitu berupa ThreeTier-Test (TTT) dalam bentuk pilihan ganda yang berisi pengujian mengenai materi listrik dinamis. Tes ini digunakan untuk membedakan siswa miskonsepsi atau tidaknya yaitu dengan memberikan pertanyaan mengenai materi listik dinamis, kemudian siswa menjawab pertanyaan beserta alasan akan pilihannya dan siswa diberikan kepastian akan jawabannya dengan menjawab yakin atau tidak yakin. Adapun keputusan atas jawaban siswa dapat dilihat pada Tabel 1 yang telah diadopsi dari Kurniawan, Yudi dkk, (2016).

Tabel 1. Keputusan dalam Three Tier-Test

\begin{tabular}{cccc}
\hline Tier-1 & Tier-2 & Tier-3 & Keputusan \\
\hline Benar & Benar & Yakin & $\begin{array}{c}\text { Konsep } \\
\text { ilmiah }\end{array}$ \\
\hline
\end{tabular}

\begin{tabular}{cccc}
\hline Tier-1 & Tier-2 & Tier-3 & Keputusan \\
\hline Benar & Benar & $\begin{array}{l}\text { Tidak } \\
\text { Yakin }\end{array}$ & Lucky guess \\
\hline Salah & Benar & Yakin & Miskonsepsi \\
\hline Salah & Benar & $\begin{array}{l}\text { Tidak } \\
\text { Yakin }\end{array}$ & Guess \\
\hline Benar & Salah & $\begin{array}{l}\text { Tidak } \\
\text { Yakin }\end{array}$ & Guess \\
\hline Salah & Salah & Yakin & Miskonsepsi \\
\hline Salah & Salah & $\begin{array}{l}\text { Tidak } \\
\text { Yakin }\end{array}$ & $\begin{array}{c}\text { Lack of } \\
\text { Knowledge }\end{array}$ \\
\hline Benar & Salah & Yakin & Miskonsepsi \\
\hline
\end{tabular}

Adapun pelaksanaan model pembelajaran ILE yang dirancang oleh guru untuk siswa dalam mempelajari fenomena fisika khususnya dalam materi listrik dinamis yaitu dengan bantuan media simulasi virtual. Berikut sintaks model ILE yang diadopsi dari (Moll, Rachel dkk, 2009) yang dapat dilihat pada Tabel 2.

Tabel 2. Sintaks Model ILE

\begin{tabular}{|c|c|}
\hline $\begin{array}{c}\text { No. } \\
\text { Sintaks }\end{array}$ & Model ILE \\
\hline 1 & $\begin{array}{l}\text { Guru memberikan demonstrasi } \\
\text { berupa fenomena pada saat } \\
\text { pembelajaran dengan } \\
\text { menggunakan media simulasi } \\
\text { virtual dan siswa diminta untuk } \\
\text { menjawab pertanyaan sesuai } \\
\text { dengan konsep yang dimilikinya, }\end{array}$ \\
\hline 2 & $\begin{array}{l}\text { Guru meminta siswa untuk } \\
\text { melakukan percobaan berkaitan } \\
\text { dengan fenomena konsep fisika, }\end{array}$ \\
\hline 3 & $\begin{array}{l}\text { Siswa menganalisis percobaan } \\
\text { yang telah dilakukan sebagai tugas } \\
\text { individu, }\end{array}$ \\
\hline 4 & $\begin{array}{lrr}\text { Setelah } & \text { melakukan } & \text { percobaan } \\
\text { siswa } & \text { diminta } & \text { untuk } \\
\text { mempresentasikan } & \text { hasil } \\
\text { percobaan berupa laporan tertulis, }\end{array}$ \\
\hline 5 & $\begin{array}{l}\text { Siswa diberikan tugas untuk } \\
\text { memecahakan suatu masalah } \\
\text { lainnya yang berkaitan dengan } \\
\text { penerapan konsep fisika. }\end{array}$ \\
\hline
\end{tabular}

Untuk mendapatkan hasil perolehan nilai siswa saat pretest hingga posttest, analisis yang digunakan yaitu yang diadopsi dari (Kurniawan, Yudi dkk, 2016). 


$$
D Q M=\frac{\% \text { pretest }-\% \text { posttest }}{\% \text { pretest }-\% \text { ideal }} \times 100 \%
$$

Dengan persentase DQM yang digunakan untuk mengetahui jumlah kuantitas siswa yang mengalami penurunan miskonsepsi, berikut merupakan kategori penurunan miskonsepsi (Kurniawan, Yudi dkk, 2016) yang dapat dilihat pada Tabel 3.

Tabel 3. Kategori Penurunan Miskonsepsi

\begin{tabular}{cc}
\hline Kategori & $\begin{array}{c}\text { Interval penurunan } \\
\text { miskonsepsi }\end{array}$ \\
\hline Rendah & $0<\mathrm{DQM} \leq 30$ \\
\hline Sedang & $30<\mathrm{DQM} \leq 70$ \\
\hline Tinggi & $70 \mathrm{DQM} \leq 100$ \\
\hline
\end{tabular}

\section{HASIL DAN PEMBAHASAN}

Penelitian ini bertujuan untuk mengetahui pengaruh penerapan model pembelajaran ILE berbantuan media simulasi virtual terhadap penurunan kuantitas siswa yang miskonsepsi pada materi Listrik Dinamis. Dalam penelitian ini terdapat tujuh miskonsepsi pada sub materi Listrik Dinamis, dengan menggunakan distribusi data mengenai miskonsepsi pada materi listrik dinamis yang ditemukan peneliti dengan diberikan nomor konsep yang miskonsepsi yang mana dapat memudakan dalam pembahasan data hasil penelitan. Adapaun distibusi data dapat dilihat pada Tabel 4 .

Tabel 4. Miskonsepsi Pada Konsep Listrik

\section{Dinamis}

\begin{tabular}{cc}
$\begin{array}{c}\text { No. } \\
\text { konsep }\end{array}$ & Pernyataan Miskonsepsi \\
\hline Mis-1 & $\begin{array}{l}\text { Arus listrik adalah muatan positif } \\
\text { yang mengalir dalam konduktor } \\
\text { dari kutub positif ke kutub negatif. }\end{array}$ \\
\hline
\end{tabular}

\begin{tabular}{cl}
\hline $\begin{array}{c}\text { No. } \\
\text { konsep }\end{array}$ & \multicolumn{1}{c}{ Pernyataan Miskonsepsi } \\
\hline Mis-2 & $\begin{array}{l}\text { Kuat arus listrik yang melewati } \\
\text { setiap titik dalam suatu rangkaian } \\
\text { seri nilainya bergantung pada } \\
\text { jarak titik tersebut terhadap kutub- } \\
\text { kutub baterai. }\end{array}$ \\
\hline Besar arus listrik yang melewati \\
setiap hambatan yang dipasang \\
seri pada suatu rangkaian \\
sederhana nilainya bergantung \\
pada nilai hambatan yang \\
dilewatinya.
\end{tabular}

Setelah didapat miskonsepsi pada konsep listrik dinamis yang dimiliki oleh siswa, maka konsep tersebut didistribusikan ke beberapa pertanyaan yang akan diberikan kepada siswa.

Tabel 5. Rekapitulasi Skala Sikap

\begin{tabular}{|c|c|}
\hline Aspek Skala Sikap & Respon \\
\hline $\begin{array}{l}\text { Antusias siswa } \\
\text { terhadap model ILE } \\
\text { berbantuan media } \\
\text { simulasi virtual } \\
(86,5 \%)\end{array}$ & Positif \\
\hline $\begin{array}{l}\text { Perubahan konseptual } \\
(80,7 \%)\end{array}$ & Positif \\
\hline
\end{tabular}


Tabel 6. Rekapitulasi Keterlaksanaan Pembelajaran

\begin{tabular}{llll}
\hline $\begin{array}{c}\text { Aktivitas } \\
\text { Guru }\end{array}$ & Interpretasi & $\begin{array}{c}\text { Aktivitas } \\
\text { Siswa }\end{array}$ & Interpretasi \\
\hline Semua & & Semua & \\
kegiatan & & kegiatan & \\
$\begin{array}{l}\text { guru yang } \\
\text { terlaksan }\end{array}$ & Baik Sekali & $\begin{array}{l}\text { siswa } \\
\text { yang }\end{array}$ & Baik Sekali \\
a (100\%) & $\begin{array}{l}\text { terlaksan } \\
\text { a (98\%) }\end{array}$ & \\
\hline
\end{tabular}

Pada Tabel 5 menunjukan bahwa sebagian besar siswa memberikan respon positif terhadap model ILE berbantuan media simulasi virtual, adapun respon yang diberikan oleh siswa dapat merubah konsep yang ada pada dirinya menjadi konsep ilmiah. Saat guru memberikan model ILE berbantuan media simulasi virtual hampir seluruh siswa melakukan aktivitas atau aktif di dalam kelas (dapat dilihat pada Tabel 6).

Berdasarkan hasil analisis keputusan three tier-test (TTT) dengan membandingkan hasil pretest dan posttes, maka didapat penurunan kuantitas siswa yang miskonsepsi dapat dilihat pada Gambar 1.

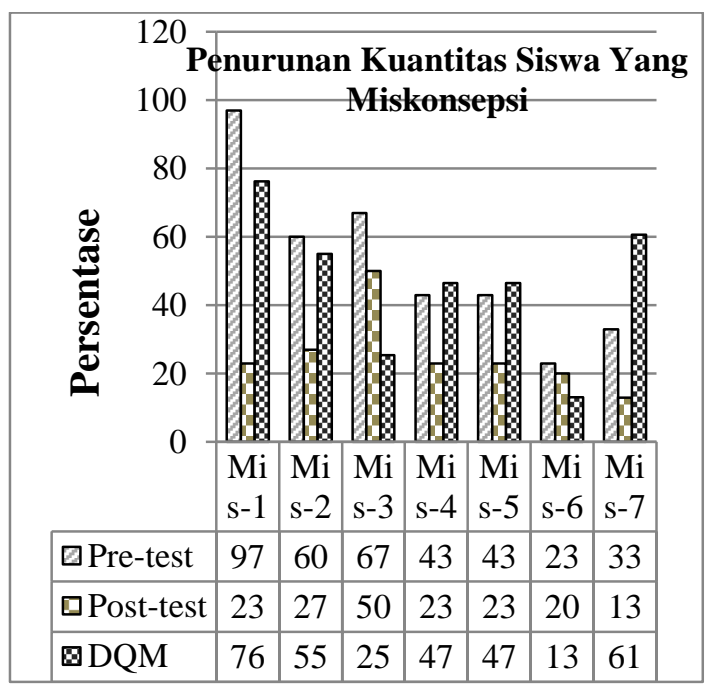

Gambar 1. Penurunan Kuantitas Siswa Yang Miskonsepsi Pada Materi Listrik Dinamis.
Pada Gambar 1 kuantitas siswa yang miskonsepsi tertinggi pada Mis-1 sebesar 97\% berdasarkan hasil pretest. Kuantitas siswa yang miskosepsi terendah pada Mis-6 yaitu sebesar $23 \%$ dari hasil pretest. Adapun penurunan kuantitas siswa yang miskonsepsi dengan persentase terbesar (76\%) pada Mis-1, dapat dilihat bahwa kuantitas siswa yang miskonsepsi pada Gambar 1 sekilas mengalami penurunan. Dapat dilihat pada Tabel 7 merupakan kategori penurunan kuantitas siswa yang miskonsepsi pada setiap konsep yang miskonsepsi.

Tabel 7. Kategori Penurunan Kuantitas Siswa Yang Miskonsepsi (DQM)

\begin{tabular}{cc}
\hline $\begin{array}{c}\text { No. } \\
\text { Konsep }\end{array}$ & Kategori DQM \\
\hline Mis-1 & Tinggi \\
\hline Mis-2 & Sedang \\
\hline Mis-3 & Rendah \\
\hline Mis-4 & Sedang \\
\hline Mis-5 & Sedang \\
\hline Mis-6 & Rendah \\
\hline Mis-7 & Sedang \\
\hline
\end{tabular}

Penelitian ini memberikan bukti bahwa pembelajaran ILE dapat membantu menurunkan kuantitas siswa yang miskonsepsi yaitu berdasarkan hasil analisis DQM sebesar 46,3\% dengan kategori sedang. Model ILE berbantuan media simulasi virtual dirancang untuk menimbulkan konflik kognitif pada siswa, terutama pada sintaks kedua yaitu eksperimen. Pada sintaks kedua ini, sebelum melakukan percobaan siswa diberikan pertanyaan arahan dan setelah siswa menjawab berdasarkan konsep awal yang mereka miliki, kemudian siswa melakukan eksperimen terkait pertanyaan yang diberikan dan siswa akan merasa bahwa jawaban mereka dengan konsep awalnya berbeda setelah dilakukan percobaan. 
Saat diberikan pertanyaan arahan sebelum dilakukan percobaan, misalkan: "apabila salah satu pada rangkaian tersebut terbuka yaitu pada lampu $B$, bagaimana beda potensial pada kedua ujung lampu A dan lampu B? Jelaskan!". Siswa yang mengalami miskonsepsi akan menjawab "beda, karena lampu B rangkaiannya terbuka dan lampu A rangkaiannya tertutup" dengan menjawab yakin.

Setelah dilakukan percobaan, mereka mengamati sendiri bahwa besar beda potensial listrik jika probe volmeter dipasang pada ujungujung lampu B makan hasilnya akan sama. Fenomena ini menimbulkan konflik kognitif pada benak siswa karena konsepsi mereka berbeda dengan hasil percobaan yang telah dilakukannya. Kemudian guru memberikan penguatan dengan menggunakan simulasi virtual sehingga siswa akan lebih paham.

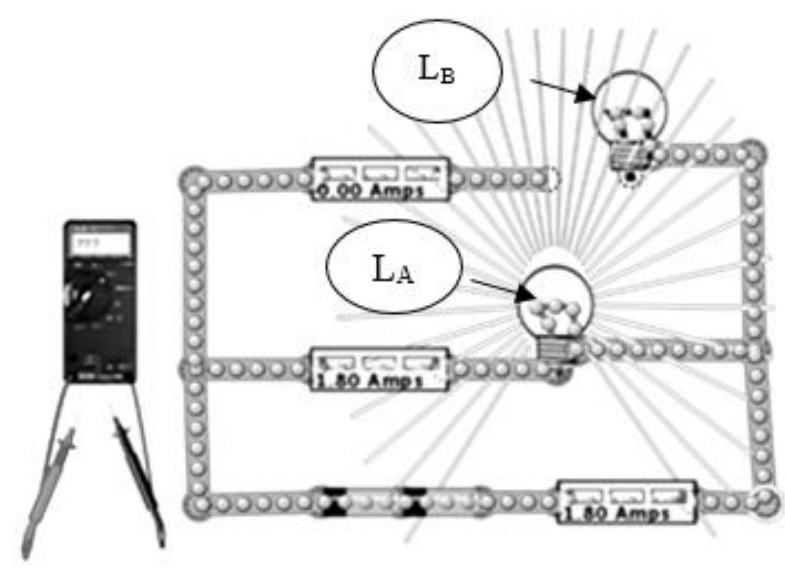

Gambar 2. Tampilan Simulasi Virtual

Apabila seseorang memahami suatu konsep yang telah dipelajari, mengetahui yang sedang dibahas, dan dapat menjelaskan dengan benar maka orang tersebut dikatakan memiliki pemaham konsep yang baik (Kurniawan, 2016). Akan tetapi adanya miskonsepsi yang dialami oleh siswa bisa dikarenakan kurang optimalnya rekonstruksi konsep yang menyebabkan siswa tersebut kurang fokus mengikuti tahap-tahap pembelajaran sehingga siswa kurang mampu dalam mengasimilasi atau mengakomodasi konsep yang dimilikinya (Hikmat, dkk, 2014). Dalam penelitian ini ditemukan beberapa siswa yang masih mengalami kesulitan dalam mengamati simulasi virtual yang ditampilkan dan saat melakukan eksperimen serta melakukan analisis percobaan, sehingga untuk peneliti selanjutnya ditekankan untuk membuat kelompok belajar kecil agar dalam pembelajaran selanjutnya peneliti akan lebih mudah mengawasi siswa dalam bereksperimen atau akan lebih mudah dalam pengambilan data.

\section{KESIMPULAN DAN SARAN}

Berdasarkan analisis data terhadap miskonsepsi siswa pada materi Listrik Dinamis setelah diterapkan model pembelajaran Interactive Lecture Experiment (ILE) berbantuan media simulasi virtual dapat menurunkan kuantitas siswa yang miskonsepsi dengan ratarata $46,3 \%$ berkategori sedang. Penurunan kuantitas siswa yang miskonsepsi dengan persentase terbesar (76\%) yaitu "arus listrik adalah muatan positif yang mengalir dalam konduktor dari kutub positif baterai menuju kutub negatif baterai".

\section{DAFTAR PUSTAKA}

Hikmat; Tayubi, Yuyu. R; Purwana, Unang; dan Suhandi, Andi. 2014. Strategi Konflik Kognitif Berbantuan Media Simulasi Virtual Dalam Pembelajaran Fisika Berorientasi 
Pengubahan Konseptual Untuk

Meningkatkan Pemahaman Konsep Dan Menurunkan Kuantitas Siswa Yang Miskonsepsi. Prosiding Pertemuan IImiah XXVIII HFI Jateng \& DIY, Yogyakarta, 342347.

Kurniawan, Yudi. 2016. Pengaruh Penerapan Interactive Lecture Demonstration (ILD) Berorientasi Connceptual Change Terhadap Peningkatan Pemahaman Konsep Siswa Pada Materi Hukum Newton. Jurnal Penelitian Pendidikan, ejournal.upi.edu, 61-68.

Kurniawan, Yudi., Andi Suhandi., and Lilik Hasanah. 2016. The influence of implementation of interactive lecture demonstrations (ILD) conceptual change oriented toward the decreasing of the quantity students that misconception on the Newton's first law. AIP Conference Proceedings. Eds. Topik Hidayat, et al. Vol. 1708. No. 1. AIP Publishing. 1-5. doi.org/10.1063/1.4941180.

Milner-Bolotin, Marina; Kotlicki, Andrzej and Rieger, Georg. 2007. Can Students Learn From Lecture Demonstrations?. The Role and Place of Interactive Lecture Experiments in Large Introductory Science Courses. Journal of College Science Teaching, 45-49.

Moll, Rachel F and Milner-Bolotin, Marina. 2009.

The Effect of Interactive Lecture Experiments on Student Academic Achievement and Attitudes Towards Physics. NRC Research Press Journal Physics 87, 197-198. doi:10.1139/P09048.
Muna, I. Auliyatul. 2015. Identifikasi Miskonsepsi Mahasiswa PGMI Pada Konsep Hukum Newton Menggunakan Certainty of Response Index (CRI). Administrasi Pendidikan. Cendikia 13 (2), 312-322.

Pebriyanti, Dwi; Sahidu, Hairunnisyah dan

Sutrio. 2015. Efektifitas Model

Pembelajaran Perubahan Konseptual Untuk Mengatasi Miskonsepsi Fisika Pada Siswa Kelas X SMAN 1 Praya Barat Tahun Pelajaran 2012/2013. Jurnal Pendidikan Fisika dan Teknologi 1 (1), 92-96.

Suniati, N. M. Sari; Sadia, Wayan; dan Suhandana, A. 2013. Pengaruh Implementasi Pembelajaran Kontekstual Berbantuan Multimedia Interakif Terhadap

Penurunan Miskonsepsi. e-Jurnal Program Pascasarjana Universitas Pendidikan Ganesha. Program Studi Administrasi Pendidikan 4 (1), 1-13.

Suparno, P. 2005. Miskonsepsi dan Perubahan Konsep Dalam Pendidikan Fisika. Yogyakarta. 